Bangl. J. Vet. Med. (2006). 4 (2): 129-132

\title{
EFFECT OF CONCENTRATE SUPPLEMENTATION ON GROWTH AND REPRODUCTIVE PERFORMANCE OF RABBIT UNDER RURAL CONDITION
}

\author{
M. S. Hasanat ${ }^{1}$, M. E. Hossain ${ }^{2}$, M. P. Mostari ${ }^{3}$ and M. A. Hossain ${ }^{4}$ \\ Department of Animal Nutrition, Faculty of Animal Husbandry, Bangladesh Agricultural University, \\ Mymensingh-2202, Bangladesh
}

\begin{abstract}
Crossbred New Zealand White meat type 8 male and 16 female rabbits aged 3.5 to 4.5 months weighing 9.5 to $13.0 \mathrm{~kg}$ were used in a 128 day trial to study the effects of concentrate supplementation on growth and reproductive performance of rabbit under rural condition. Rabbits were divided according to live weight into two treatment groups, i.e. $\mathrm{T}_{1}$ (conventional diet) and $\mathrm{T}_{2}$ (conventional diet + concentrate $75 \mathrm{~g} / \mathrm{d}$ per rabbit) with four replications per treatment in a Complete Randomized Design (CRD). All animals had free access to locally available green grasses. Results showed that, average daily live weight gain was significantly ( $<<0.01)$ higher in $\mathrm{T}_{2}(13.02 \pm 0.43 \mathrm{~g} / \mathrm{d})$ than $\mathrm{T}_{1}(5.30 \pm 0.43 \mathrm{~g} / \mathrm{d})$ group. Litter weight at birth was better $(\mathrm{p}<0.05)$ in $\mathrm{T}_{2}(180.38 \pm 16.37 \mathrm{~g})$ than $\mathrm{T}_{1}(137.19 \pm 16.37 \mathrm{~g})$ group. Litter size at weaning differed $(\mathrm{p}<0.05)$ and the mean values were $1.37 \pm 0.30$ for $\mathrm{T}_{1}$ and $2.37 \pm 0.27$ for $\mathrm{T}_{2}$ group. Kit weight at weaning was superior $(\mathrm{p}<0.01)$ in $\mathrm{T}_{2}$ $(408.12 \pm 3.85 \mathrm{~g})$ than $\mathrm{T}_{1}(310.62 \pm 3.56 \mathrm{~g})$ group. Kit mortality up to weaning was higher $(\mathrm{p}<0.01)$ in $\mathrm{T}_{1}(45.0 \pm 10.07 \%)$ than $\mathrm{T}_{2}(26.92 \pm 10.7 \%)$ group. These results indicate that, supplementation of concentrate in addition to conventional feeding may improve growth and reproductive performance of rabbit under rural condition.
\end{abstract}

Key words: Crossbred, New Zealand White rabbit, reproductive performance, growth, concentrate

\section{INTRODUCTION}

Bangladesh is an overpopulated country of south Asia. Of all the problems of Bangladesh acute crisis of human food particularly animal protein tops the list. Due to higher density of population the country is suffering from severe shortage of livestock products like meat, milk and egg. At present meat produced by cattle, buffalo, goat, sheep and poultry is quite insufficient to meet up the growing demand of animal protein. So, now it is important to explore some alternative sources of animal protein to minimize the deficiency of protein. Rabbit an important microlivestock (Vietmeyer, 1985) may be considered as a promising and potential alternative source of protein in this regard. Recently small scale rabbit projects are gaining international attention day by day as a means of alleviating poverty threat (FAO, 1996). Agro-climatic condition, religious point of view, social practices and technological aspects support the prospects and potentials of raising rabbit (MIDAS, 1992). Rabbit meat is low in fat and cholesterol (Jones, 1990). Skin of rabbit may be used in toy, crafts and cottage industry. Moreover, rabbit occupies a vital midway between ruminants and monogastric animals. Rabbit can effectively utilize cellulose rich feed with ration containing less than $20 \%$ grain. Simple biological characteristics, short breeding cycle, high prolificacy and better feed conversion efficiency logically place rabbit just below poultry.

Present address : ${ }^{1}$ Executive, CP Bangladesh Co. Ltd., ${ }^{2}$ Department of Animal Science and Nutrition, Chittagong Veterinary and Animal Sciences University, Chittagong, ${ }^{3}$ Bangladesh Livestock Research Institute, Savar, Dhaka, ${ }^{4}$ Department of Dairy and poultry Science, Chittagong Veterinary and Animal Sciences University, Chittagong. 
Rabbit production system practiced in the rural areas under traditional condition is mainly forage-based. The poor and unbalanced quality of grasses is a major constraint, which limits the successful production of rabbits. Cheeke and Raharjo (1988) concluded from a review of rabbit production on tropical feed resources that tropical grasses were unsuitable as the sole feed for rabbits due to their low digestibility (less than $10 \%$ ). However, rabbits can successfully be raised on diets that are low in grains and high in roughage (Cheeke, 1986). Growing rabbits can be maintained satisfactorily on diets consisting of 100 to $200 \mathrm{~g}$ green roughage and 40 to $60 \mathrm{~g}$ concentrate mixtures for maximum production (Ranjhan, 1980). Limited works have been done for overall improvement of rabbit. Therefore, present research was undertaken to observe the effect of concentrate supplementation on growth and reproductive performance of rabbit under rural condition.

\section{MATERIALS AND METHODS}

The experiment was conducted for a period of 90 days from January 01 to March 31, 2002 at farmers homestead Lokkhikhola village in Muktagacha Upazila of Mymensingh district, Bangladesh, with the help of a local NGO "Jalal Nagar Development Project (JNDP)". Crossbred New Zealand White meat type 8 male and 16 female rabbits aged between 3.5 to 4.5 months weighing 9.5 to $13.0 \mathrm{~kg}$ were used in a 128 day trial to study the effects of concentrate supplementation on growth and reproductive performance of rabbit under rural condition. The rabbits were divided into two treatment groups, i.e. $T_{1}$ (conventional diet) and $T_{2}$ (conventional diet + concentrate $75 \mathrm{~g} / \mathrm{d}$ per rabbit) with four replications, i.e. $\mathrm{R}_{1}, \mathrm{R}_{2}, \mathrm{R}_{3}$, and $\mathrm{R}_{4}$ per treatment in a Complete Randomized Design (CRD). All rabbits were housed individually in locally made cases measuring $40 \times 20$ x 60 cubic $\mathrm{cm}$. Each cage was equipped with a nest box at the time of parturition. For feeding and watering, farmers used earthen pot as feeder and drinker. Concentrate mixture was prepared following the guideline of NRC with $16.7 \mathrm{~g} / 100 \mathrm{~g}$ crude protein and $2700 \mathrm{Kcal} \mathrm{ME} / \mathrm{kg} \mathrm{DM}$. The diet was fortified with vitamin mineral premix. Animals were fed in two groups. Each rabbit of $\mathrm{T}_{1}$ group was fed boiled rice, road side grass, banana leaf, cabbage, cauliflower and radish while $\mathrm{T}_{2}$ group was supplemented with additional concentrate @ 75 g/d per rabbit. Feeds were analyzed in the Animal Nutrition Laboratory, Bangladesh Agricultural University, Mymensingh, Bangladesh followed by AOAC (1984). Data were analyzed following Steel and Torrie (1980). Differences among treatment were determined using t-test. Contrast comparison was applied (SAS, 1996) to test the significance of the treatment effects.

Table 1. Ingredient and nutrient composition of the diet

\begin{tabular}{|lc|}
\hline Items & Amount (g / 100 g) \\
\hline Ingredients & 35.0 \\
Maize & 25.0 \\
Wheat & 15.0 \\
Wheat bran & 15.0 \\
Til oil cake & 9.50 \\
Soybean meal & 0.50 \\
Common salt & 0.25 \\
Vitamin mineral premix & \\
Nutrient composition & 16.7 \\
Crude protein & 2698 \\
Metabolizable energy (Kcal/kg) & 0.37 \\
Calcium & 0.23 \\
Phosphorus & \\
\hline
\end{tabular}

\section{RESULTS AND DISCUSSION}

Results showed that initial average live weight of rabbits did not differ significantly $(\mathrm{p}>0.05)$ and the mean values were $1055.83 \pm 59.20 \mathrm{~g}$ and $994.98 \pm 58.27 \mathrm{~g}$ in $\mathrm{T}_{1}$ and $\mathrm{T}_{2}$ group respectively (Table 2). However, final average live weight differed significantly $(\mathrm{p}<0.01)$ and the mean values were $1426.66 \pm 63.42$ and $1911.66 \pm$ $61.28 \mathrm{~g}$ in $\mathrm{T}_{1}$ and $\mathrm{T}_{2}$ group respectively. Average daily live weight gain was significantly $(\mathrm{p}<0.01)$ higher in $\mathrm{T}_{2}$ ( $13.02 \pm 0.43 \mathrm{~g} / \mathrm{d})$ than in $\mathrm{T}_{1}(5.30 \pm 0.43 \mathrm{~g} / \mathrm{d})$ group. This finding is in close agreement with Farinu (1994) who 
found average daily live weight gain of rabbit to be $15.2 \mathrm{~g} / \mathrm{d}$ using compound diet containing $30 \%$ soybean meal. However, this study does not support the observation of Pote et al. (1980) who found growth rate of rabbit to be $25 \mathrm{~g} / \mathrm{d}$ when fed fresh green clover vegetable leaves with no supplementation. In another study, the highest growth rate on the fish meal supplement was the logical consequence of the superior amino acid balance of this protein source, compared with cottonseed cake and soybean cake (McDonald et al., 1973), but surprisingly this was not reflected in a better feed conversion. In fact, rice bran, cassava root, sweet potato and bananas are available and potential alternatives of cereal grains for rabbits under rural condition.

Table 2. Effect of concentrate supplementation on growth and reproductive performance of rabbit

\begin{tabular}{|llll|}
\hline Parameters & \multicolumn{2}{l|}{ Treatment group } & \multicolumn{2}{l}{$\begin{array}{l}\text { Level of } \\
\text { significance }\end{array}$} \\
\cline { 2 - 4 } & $\mathrm{T}_{1}$ & $\mathrm{~T}_{2}$ & \\
\hline Initial live weight (g) & $1055.83 \pm 59.20$ & $994.98 \pm 58.27$ & $\mathrm{NS}$ \\
Final live weight (g) & $1426.66^{\mathrm{b}} \pm 63.42$ & $1911.66^{\mathrm{a}} \pm 61.28$ & $* *$ \\
Live weight gain (g/d) & $5.30^{\mathrm{b}} \pm 0.43$ & $13.02^{\mathrm{a}} \pm 0.43$ & $* *$ \\
Conception rate (\%) & 100 & 100 & $\mathrm{NS}$ \\
Gestation period (d) & $32.43 \pm 0.49$ & $31.89 \pm 0.49$ & $\mathrm{NS}$ \\
Litter size at birth & $2.5 \pm 0.29$ & $3.25 \pm 0.29$ & NS \\
Litter weight at birth (g) & $137.19^{\mathrm{b}} \pm 16.37$ & $180.38^{\mathrm{a}} \pm 16.37$ & $*$ \\
Litter size at weaning & $1.37^{\mathrm{b}} \pm 0.30$ & $2.37^{\mathrm{a}} \pm 0.27$ & $*$ \\
Kit weight at birth (g) & $54.87 \pm 0.96$ & $55.5 \pm 0.96$ & NS \\
Kit weight at weaning (g) & $310.62^{\mathrm{b}} \pm 3.56$ & $408.12^{\mathrm{a}} \pm 3.85$ & $* *$ \\
Kit mortality up to weaning (\%) & $45.0^{\mathrm{b}} \pm 10.07$ & $26.92^{\mathrm{a}} \pm 10.7$ & $* *$ \\
\hline
\end{tabular}

Reproductive performance of kits of groups $T_{1}$ and $T_{2}$ fed diets are presented in Table 2. Percentage of does kidded is one of the most important measurement for reproductive performance. In this study percentage of does kidded was $100 \%$ for both $\mathrm{T}_{1}$ and $\mathrm{T}_{2}$ group. All does gave birth within the study period. The average gestation period of the rabbit did not differ significantly ( $p>0.05$ ) and the mean values were $32.43 \pm 0.49$ and $31.89 \pm 0.49$ days for $T_{1}$ and $T_{2}$ group respectively. This observation is in close agreement with Yono et al. (1986). Ehiobu et al. (1997) also found the gestation period of Newzealand White rabbit to be $31.8 \pm 0.11$ day. Omole (1982) found the gestation period of does to be 31.2 days on $18 \%$ crude protein based diet. However no differences ( $>0.05$ ) were observed among conception rate (\%), gestation period (d) and litter size at birth irrespective of level of feeding.

Litter weight at birth $(g)$ and litter size at weaning differed significantly $(\mathrm{p}<0.05)$ and the mean values were (137.19 \pm 16.37$),(1.37 \pm 0.30)$ for $\mathrm{T}_{1}$ and $(180.38 \pm 16.37),(2.37 \pm 0.27)$ for $\mathrm{T}_{2}$ group respectively. Yono et al. (1986) and Sanchez et al. (1985) found no significant differences ( $>>0.05)$ in litter size and litter weight of kits at 28 days of weaning. Ayyat et al. (1996) reported that does fed $18.4 \%$ crude protein based diet had higher weaning weight than those fed diet containing $16.3 \%$ crude protein. Ayyat et al. (1996) also found that supplimentation of does with diet containing $0.1 \%$ lactose increased litter size, litter weight and total milk yield. Kit weight $(\mathrm{g})$ and kit mortality (\%) up to weaning were $(310.62 \pm 3.56),(45.0 \pm 10.07)$ for $\mathrm{T}_{1}$ and $(408.12 \pm$ 3.85), (26.92 \pm 10.7$)$ for $T_{2}$ group respectively. Yono et al.(1986) also reported less mortality of kits on low protein diet (17.5\% CP). These results indicate that supplementation of concentrate (75 g/d per rabbit) in addition to conventional feeding may improve growth and reproductive performance of rabbit under rural condition.

\section{REFERENCES}

1. AOAC (1984). Official Methods of Analysis.13th edn., Association of Official Analytical Chemists, Washington, DC.

2. Ayyat MS, Marai IFM and El-Aasar TA (1996). New Zealand white rabbit does and their growing offsprings as affected by diets containing different protein level with or without lacto-sacco supplementation. World Rabbit Science 4: 225230. 
3. Brown S (1994). Care of Rabbits. Working handout for clients. Midwest Bird and Exotic Animal Hospital, Westchester, Il.

4. Cheeke PR (1986). Potentials of rabbits production in tropical and subtropical agricultural systems. Journal of Animal Science 63: 1581-1586.

5. Cheeke PR and Raharjo C (1988). Evaluacions de forrajes tropicales y subpcoductos agricdes como alimento pava conejos. In: Sistemas Intensivos para la Produccion. Animal y de Energia Renovable con Recursos Tropicales (Editors: T.R Preston and M. Rosales) CIPAV: Cali Tomo II pp 33-42.

6. Ehiobu NG, Utim A and Gwaza SD (1997). Some observations on reproductive performance of rabbits obtained in semi-humid tropical conditions in Nigeria. World Rabbit Science 5 : 47-49.

7. FAO (1996). World Food Summit Plan of Action. Food and Agriculture Organization of the United Nations, Rome, Italy.

8. Farinu GO (1994). Effect of feeding a compound diet based on non-conventional feed stuffs on growth and characteristics of rabbits. World Rabbit Science 2 : 123-126.

9. Jones ND (1990). The developing market for farm bred meat rabbit in Britain. Animal Production 50: 66A.

10. McDonald P, Edwards RA and Greenhalgh JFD (1988). Animal Nutrition. 4th edn., Longman Scientific and Technical, John Wiley and Sons, Institute, New York. P 398-418

11. MIDAS (1992). Prospects of commercial rabbit raising in Bangladesh a survey report. Micro Industries Development Assistance Society. National Academy Press, Washington, DC.

12. Omole TA (1982). The effect of level of dietary protein on growth and reproductive performance in rabbits. Journal of Applied Rabbit Research 5 : 83-88.

13. Pote LM, Cheeke PR and Patton NM (1980). Use of greens as a supplement to a pelleted diet for growing rabbits. Journal of Applied Rabbit Research 3 : 15-20.

14. Ranjhan SK (1980). Animal Nutrition in the Tropics. 3rd edn., Vikas Publishing House Pvt. Ltd., Sahibabab, Ghaziabad, New Delhi. P: 335.

15. Sanchez WK, Cheeke PR and Patton NM (1985). Effect of dietary crude protein level on the reproductive performance and growth of New Zealand white rabbits. Journal of Animal Science 60: 1029-1039.

16. SAS (1996). SAS system for Windows version 6.12. Statistical Analysis System Institute Inc. Cary, NC 27513, USA.

17. Steel RGD and Torrie JH (1980). Principles and Procedures of Statistics. 2nd edn., McGraw Hill Book Co., Inc., USA.

18. Vietmeyer ND (1985). Potentials of micro livestock in developing countries. Journal of Applied Rabbit Research 8:16.

19. Yono C, Raharj C, Cheeke PR and Patton NM (1986). Growth and reproductive performance of rabbits on a moderately low crude protein diet with or without methionine or urea supplementation. Journal of Animal Science 63: 795-803. 